\title{
Regular wintering of Jack Snipe (Lymnocryptes minimus) in NW Italian heathland habitat
}

\author{
Andrea Battisti ${ }^{1 *}$, Giovanni Soldato ${ }^{2}$
}

\begin{abstract}
The regularization of the wintering status of the Jack Snipe (Lymnocryptes minimus) in NW Italy has been confirmed for the first time within the heathland of the "Baraggia di Candelo Natural Reserve" (Piedmont, Biella). Regular monitoring from winter 2009/2010 to winter 2015/2016 allowed to describe the phenology and the abundance of the species in the area comparing it with that of an ally species, the Common Snipe (Gallinago gallinago). A maximum count of 6 birds during winter and at least 13 individuals during the spring migration were recorded. The species was more abundant during the second 10-day period of November and the first 10-day period of March. Jack Snipe outnumber the Common Snipe throughout the period they were censused.
\end{abstract}

Key words - wintering, Italy, heathland, phenology, waders, migration, military area.

Riassunto - Svernamento regolare di Frullino (Lymnocryptes minimus) nelle brughiere dell'Italia nod-occidentale.

Il Frullino (Lymnocryptes minimus) viene confermato per la prima volta come specie svernante regolare in Italia Nord occidentale, all'interno della brughiera della "Riserva Naturale Baraggia di Candelo" (Piemonte, Biella). Il monitoraggio regolare dall'inverno 2009/2010 all'inverno 2015/2016 ha permesso di descrivere la fenologia della specie e di valutarne l'abbondanza nell'area indagata in confronto con quella del Beccaccino (Gallinago gallinago). È stato registrato un conteggio giornaliero massimo di 6 individui in periodo invernale e di 13 individui durante la migrazione primaverile. La specie risulta più abbondante nella seconda decade di novembre e nella prima decade di marzo. Il Frullino è risultato più numeroso del Beccaccino durante tutto il periodo di riferimento.

Parole chiave - svernamento, Italia, brughiera, fenologia, migrazione, area militare.

\section{INTRODUCTION}

The Jack Snipe Lymnocryptes minimus (Brünnich, 1764) is a Palearctic long-distance migrant. The winter di-

\footnotetext{
${ }^{1}$ Frazione Feilley $n^{\circ} 101,11027$ Saint Vincent (AO), Italia

${ }^{2}$ GPSO - Museo di Storia Naturale, Via San Francesco di Sales 188, 10022 Carmagnola (TO), Italia.

E-mail: ; giovanni.soldato@gmail.com

* Corresponding author: andre.battisti@gmail.com

(C) 2018 Andrea Battisti, Giovanni Soldato
}

Received: 14 November 2016

Accepted for publication: 27 October 2017 stribution of the species is wide and not properly known. In Europe the $2.5^{\circ} \mathrm{C}$ January isotherm seems to mark the northern limit of distribution of the species (Glutz von Blotzheim et al., 1977; Géroudet, 1983); however, some individuals were recorded in winter also in colder areas such as the Great Britain, the Northern France, Denmark, Germany, Poland and Lithuania (Beck \& Olivier, 1998; Olivier, 2007). In Italy, the Jack Snipe is present regularly only during migration and in winter (Brichetti \& Fracasso, 2004), while it breeds further North in Europe. In Piedmont, the species is considered a regular migrant and irregular wintering species (Pavia \& Boano, 2009), while in Aosta Valley and Liguria it is considered as a vagrant (Bocca \& Maffei, 2010; Baghino et al., 2012).

The reason of the sparse knowledge about Jack Snipe winter distribution is due its cryptic behaviour and mimicry. Due to this reason, the regular wintering presence of Jack Snipe in NW Italy may have passed unnoticed.

The goal of the present work is to update the status of the species for Piedmont and return some information about its ecology and phenology observed in the study area.

\section{METHODS}

The study was performed in the "Baraggia di Candelo" Natural Reserve (BCNR), located in the Northern Piedmont, near the city of Biella, at an altitude of about 300 meters $(220 \div 330 \mathrm{~m})$. The area covers about 1600 hectares. It is exploited by for grazing by sheep and cows at the end of the winter and in spring time, and to military activities. The most interesting traits of this area are the moorland and meadow open landscapes shaped by Calluna vulgaris and Molina sp. as large clearings inside oak forests, and surrounded by a traditional agricultural matrix in Piedmont. Each patch of open landscape covers a surface of about 100 to 400 hectares. This area is partially included in the Natura2000 network as the SCI named "Baraggia di Candelo - cod. IT1130003", due to the presence of some European priority habitats (Habitat Dir. 92/43/ CEE - annex I) such as: "European dry heaths" (4030), "Molinia meadows on peaty or clayey-silt-laden soils (Molinion caeruleae)" (6410) and "Depressions on peat sub-strates of the Rhynchosporion" (7150) (Sindaco et 
al., 2003; 2009). The soil of the BCNR includes river clay sediments and thin aeolian sediments (loess), which determine a high impermeability of the substrate. These soil charachteristics allow the presence of temporary or semi-permanent ponds in autumn, winter and spring time. These heath areas are important for several rare and protected bird species, hosting two of the three Italian pairs of Eurasian Curlew Numenius arcuata (Scarton et. al, 2012; Battisti \& Bordignon, 2014) and an high number of two other protected species (Dir. 147/2009/ CE - annex I): Red-backed Shrike Lanius collurio, with about 30 - 35 pairs regularly present in the recent years, and European Nightjar Caprimulgus europaeus, with about 10 pairs (Battisti \& Bordignon, 2014).

The authors carried out 54 visits in the area, from the $2009 / 2010$ to the 2015/2016 winter seasons. Each cold-season was investigated from the beginning of October to the end of March. Wintering period was defined from the $1^{\text {st }}$ December to $31^{\text {st }}$ January. The visits were equally distributed throughout the season, with at least one for each month, and with a gap of at least 10-15 days between them. Censuses were performed by means of the "sweep walk" methodology, engaging one or more people, and without the help of hunting dogs. "Sweep walk" consists in walking very slowly and unpredictably (not linear) inside the area, covering as much as possible every square metre, also backtracking and stopping some times. Each one hectare-sweep walk lasted from half an hour to one hour and a half. The "sweep walks" were conducted in a sample site of about 100 hectares, inside the biggest open area of 400 hectares found in the study area. This area is a representative sample of the whole study area. Inside this study-site, three different sub-areas were identified, not bigger than 1 hectare each and with patches of shorter vegetations. During the same period Common Snipe data were also collected. During each "sweep walk" we paid particular attention to avoid double counting the same individuals, keeping in mind each landing site and discarding additional individuals in case of doubts.

\section{RESULTS}

39 records involving about 123 individuals of Jack Snipe and 24 records involving about 45 individuals of Common Snipe were overall obtained between $8^{\text {th }}$ December 2009 and $13^{\text {th }}$ March 2016. No birds were found before $2^{\text {nd }}$ November and after $29^{\text {th }}$ March (Fig. 1), despite the fact that some monitoring days were conducted before and after these dates. The maximum number of individuals observed together was 13 on the $8^{\text {th }}$ March 2014 , presumably on migration. During winter the maximum number of individuals was 6 , which was recorded twice: on $15^{\text {th }}$ January 2011 and on $26^{\text {th }}$ January 2014. The Jack Snipe was observed regularly during all winter seasons, with a minimum of 3 total individuals in the winter 2012/2013 and a maximum of 15 in the winter 2010/2011 (Fig. 2).

In the study area Jack Snipe appeared to be more frequent and abundant than the Common Snipe Gallinago gallinago (Fig.3). The latter was observed only in four winters out of a total of seven, and when present, only 1 or 2 wintering individuals per winter were found (Battisti $\&$ Bordignon, 2014).

No Jack Snipe have been observed during periods with abundant snow cover, with the exception of two birds observed on $19^{\text {th }}$ December 2010 and 3 individuals on $30^{\text {th }}$ January 2011. In these cases the snow cover was few days old and lower than five centimetres.

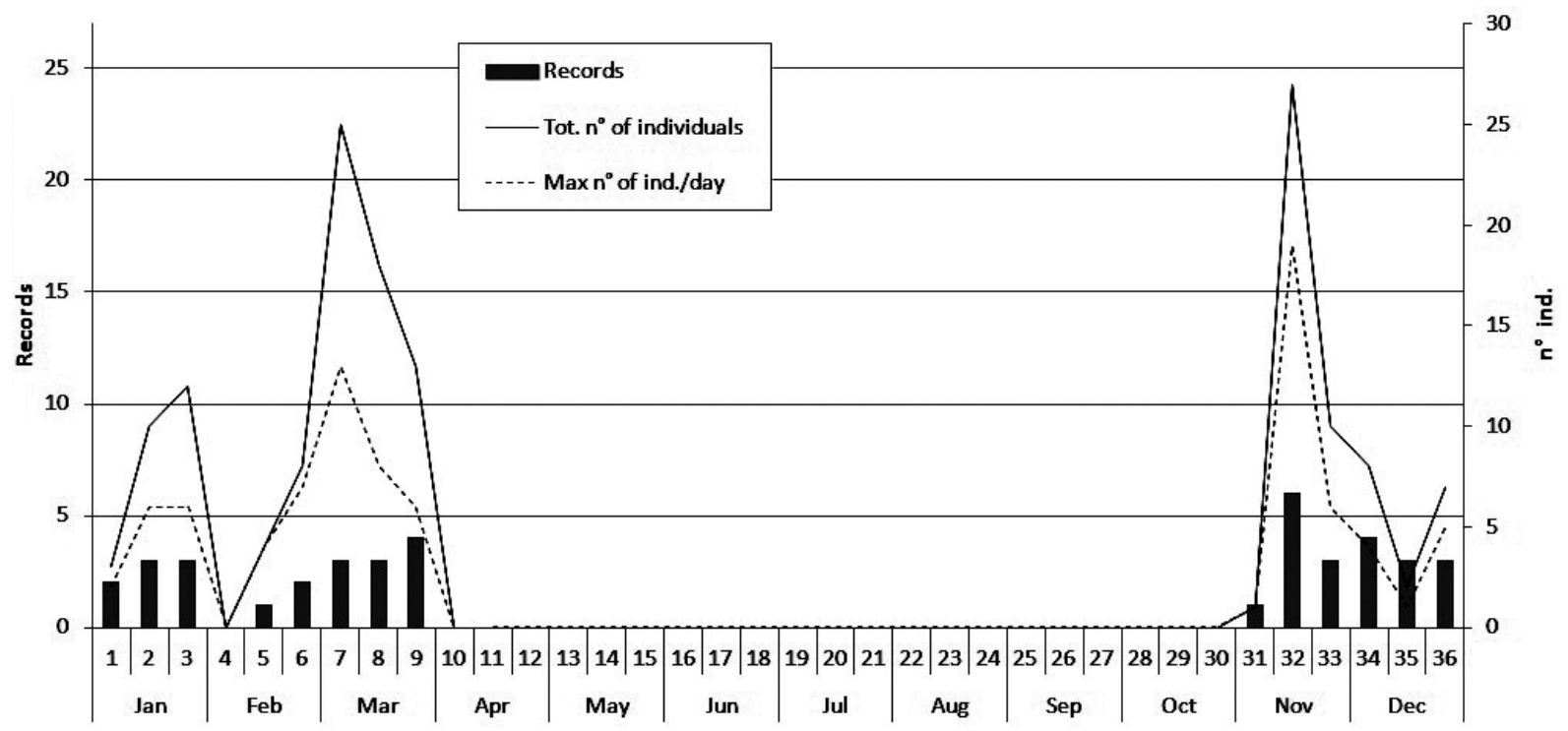

Fig. 1 - Number of Jack Snipe records in the Baraggia di Candelo Natural Reserve and maximum number of individuals per day grouped by 10 -day periods (tot. Records $=39$; tot. Individuals $=123$ ). / Numero minimo di osservazioni di Frullino nella Riserva Naturale di Baraggia di Candelo e numero massimo di individui al giorno raggruppati per periodi di 10 giorni (Tot. osservazioni = 39; tot. individui $=123$ ). 


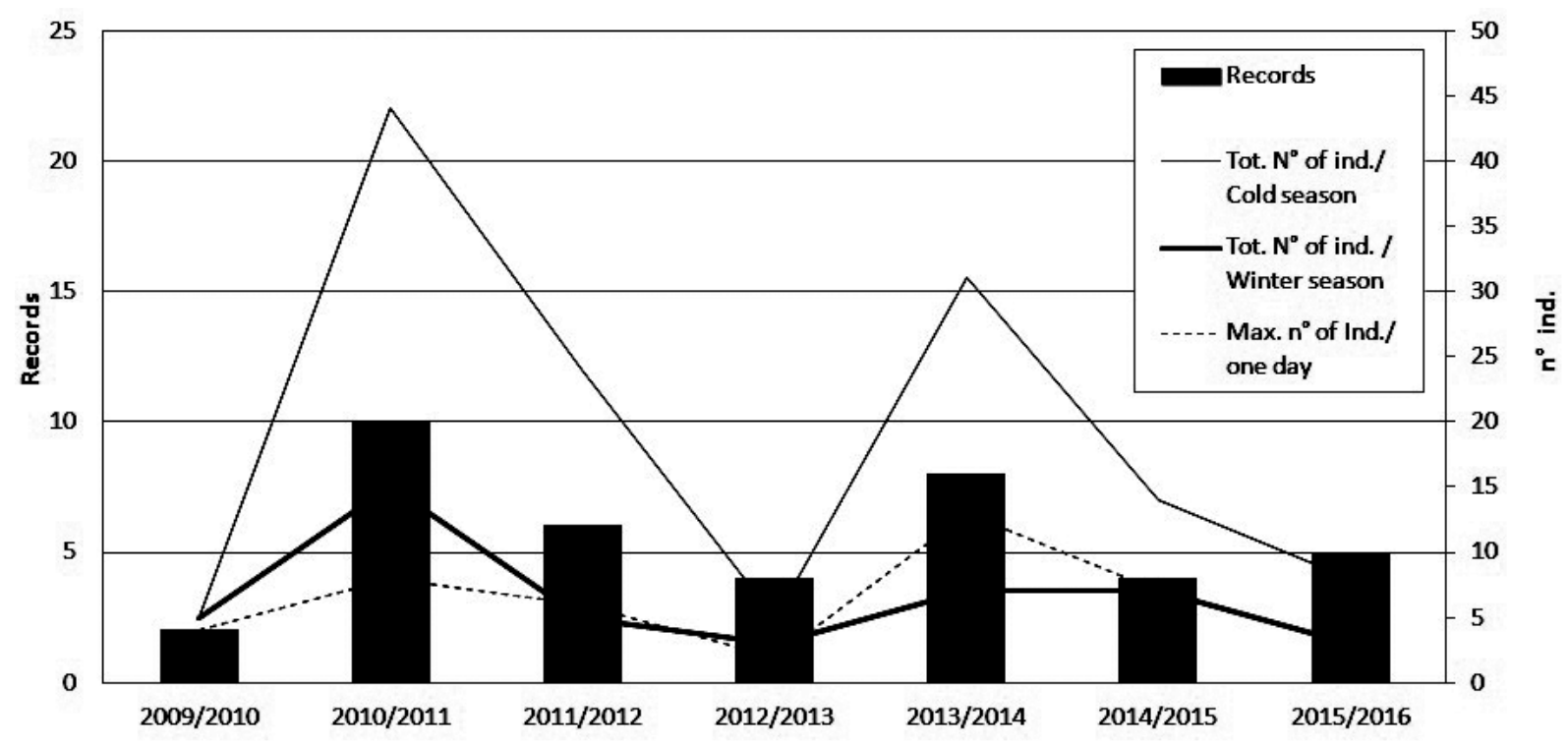

Fig. 2 - Number of records and counts of Jack snipe in the Baraggia di Candelo Natural Reserve in the last seven cold seasons (from November to the following March). The total number of individuals and the maximum daily counts for each season are reported (tot. Records $=39$; tot. Individuals $=123$ ). . Numero di osservazioni e conteggi di Frullino nella Riserva Naturale di Baraggia di Candelo nelle ultime sette stagioni fredde (da novembre al marzo successivo). Sono riportati il numero totale di individui e il numero massimo giornaliero per ogni stagione $($ Tot. osservazioni $=39$; Tot. individui $=123$ ).

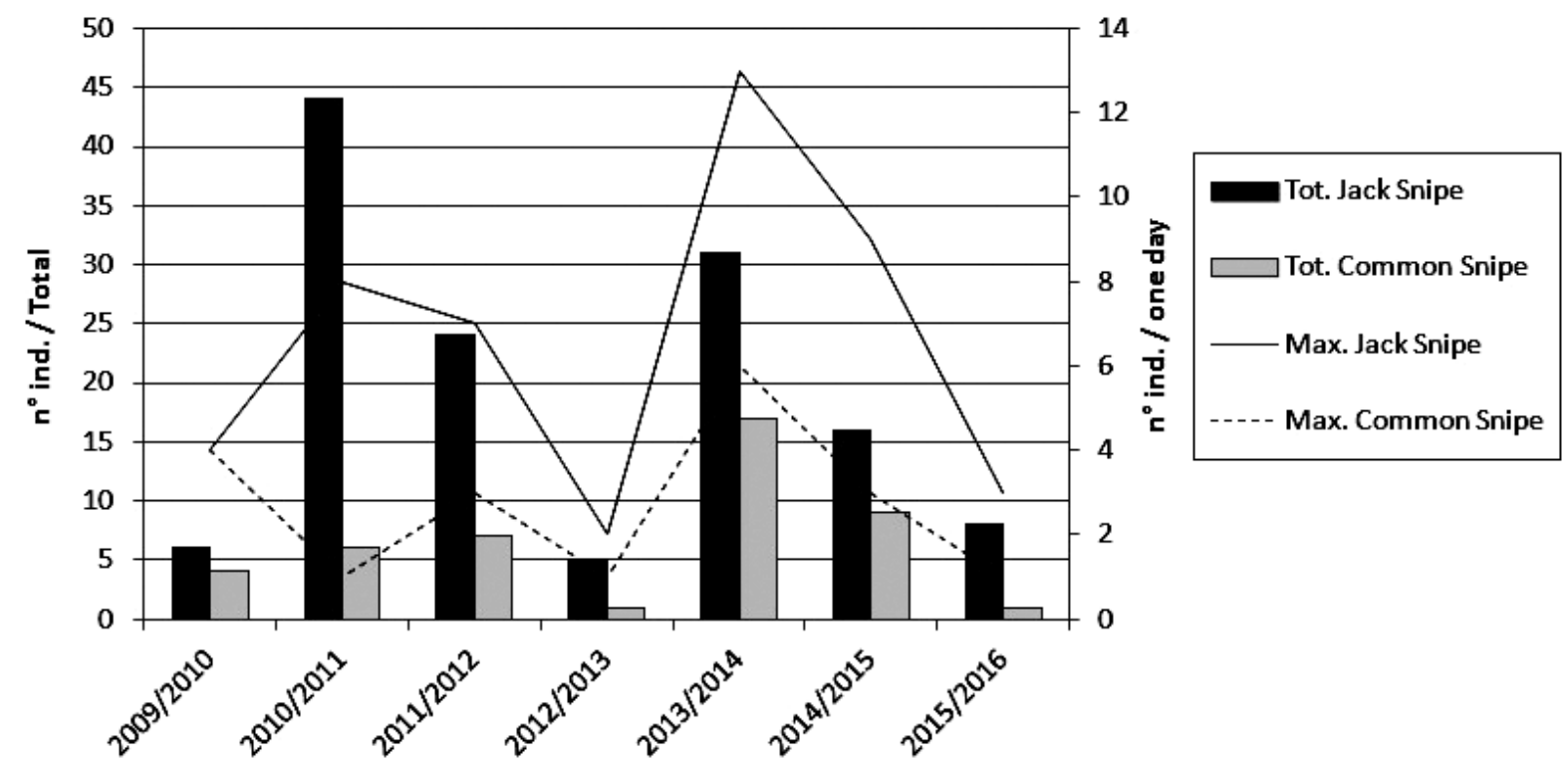

Fig. 3 - Abundances of Jack Snipe and Common Snipe in the Baraggia di Candelo Natural Reserve in the last seven cold seasons. The counts reported shown for each season the total number of birds and the maximum daily counts. The sampling days were the same for both the species (tot. Jack Snipe $=123$; tot. Common Snipe $=45$ ). / Abbondanze di Frullino e Beccaccino nella Riserva Naturale di Baraggia di Candelo nelle ultime sette stagioni fredde. I conteggi mostrano per ogni stagione il numero totale di individui e il numero massimo giornaliero. I giorni di campionamento sono stati uguali per entrambe le specie (tot. Frullino $=123$, tot. Beccaccino $=45$ ).

\section{DISCUSSION}

The Jack Snipe is a little-known species not easy to study because of its elusive behaviour. For this reason the European Jack Snipe breeding and wintering populations are not well quantified (BirdLife International, 2004). The identification of a regular site where the species is present in the Baraggia di Candelo Natural Reserve made it possible to collect several data on this bird, which is also poorly known at the Italian level.
The high relative number of birds observed during 9 years of monitoring in BCNR suggests that the Jack Snipe in NW Italy could be more common that it might seem, especially in winter. In support to this hypothesis the number of data collected in the recent cold seasons by Italian hunters, it is higher if compared with the scientific observations (Tramontana, 2014). Furthermore, in France the counts of killed birds by hunters might be enough to suggest the stability or even a slight increase 
of the West European Jack Snipe populations (Kalchreuter, 2003).

Thanks to the data from this current study and to the observations collected in the last decade in the GPSO's ornithological reports $(2005,2006,2007,2008)$, Jack Snipe was recorded in nine of the last ten years during the winter season. As a consequence, it was possible to update the status of the species in Piedmont, considering it as a regular wintering species. AERC $=$, According to the Taxonomic Advisory Committee of the Association of European Record and rarities Committees (AERC TAC, 2003) the species should be considered as A10; T (Transient) and W (Wintering). Nevertheless, this study only allow to confirm the Jack snipe as a regular wintering species, but it is not possible to confirm that individuals observed along the winter months are the same which remain in site all the season.

It is possible that the apparent increase of Jack snipe observations in the last years is due to better field prospection; however it is impossible to exclude that the species could have become regular in the region during winter due to the observed $1.5^{\circ} \mathrm{C}$ mean temperature increase recorded in the last fifty years (ARPA Piemonte, 2010). Furthermore, this increase in temperature is associated with poor snow winter cover in the area (Jacobson et al., 2004) and with reduced soil freezing (Haeberli \& Beniston, 1998), which could allow ground-feeding birds to find more suitable conditions for feeding and resting.
An unexpected result found by this study in the BCNR is the lower number of Common Snipe compared with those of the Jack snipe. This species in Piedmont is considered more widespread and abundant compared with the Jack Snipe, as confirmed by the annual GPSO's reports (from 1979 to 2015, only reports which contained at least one record of the species are listed in References). However, in the BCNR the observed pattern was the opposite (Fig. 4). These findings suggest that possibly, Jack Snipe find more suitable conditions in the heathlands than in other habitats due to particular winter habitat conditions. In fact the studied heats present an open structure and a lot of small and scattered temporary wet ponds, and bare grounds with short or dead grass (Fig. 5). Another hypothesis supporting these considerations could be due to the military restrictions that allows few human activities and help to create a relatively quiet condition. This last point is much discussed in other studies where in lot of military areas are often found patches of open suitable and quiet habitat harbouring birds and other vertebrates tied to open habitats (Vickery et al., 1994; Kershner \& Bollinger, 1996; Woinarski \& Ash, 2002; Coestfeld, 2009; Barron et al., 2012).

In conclusion, Piedmont heathlands seems to be an important key habitat for the Jack Snipe presence in NW Italy, both during migration and in winter. In support of this thesis there is the relatively high number of indivi-

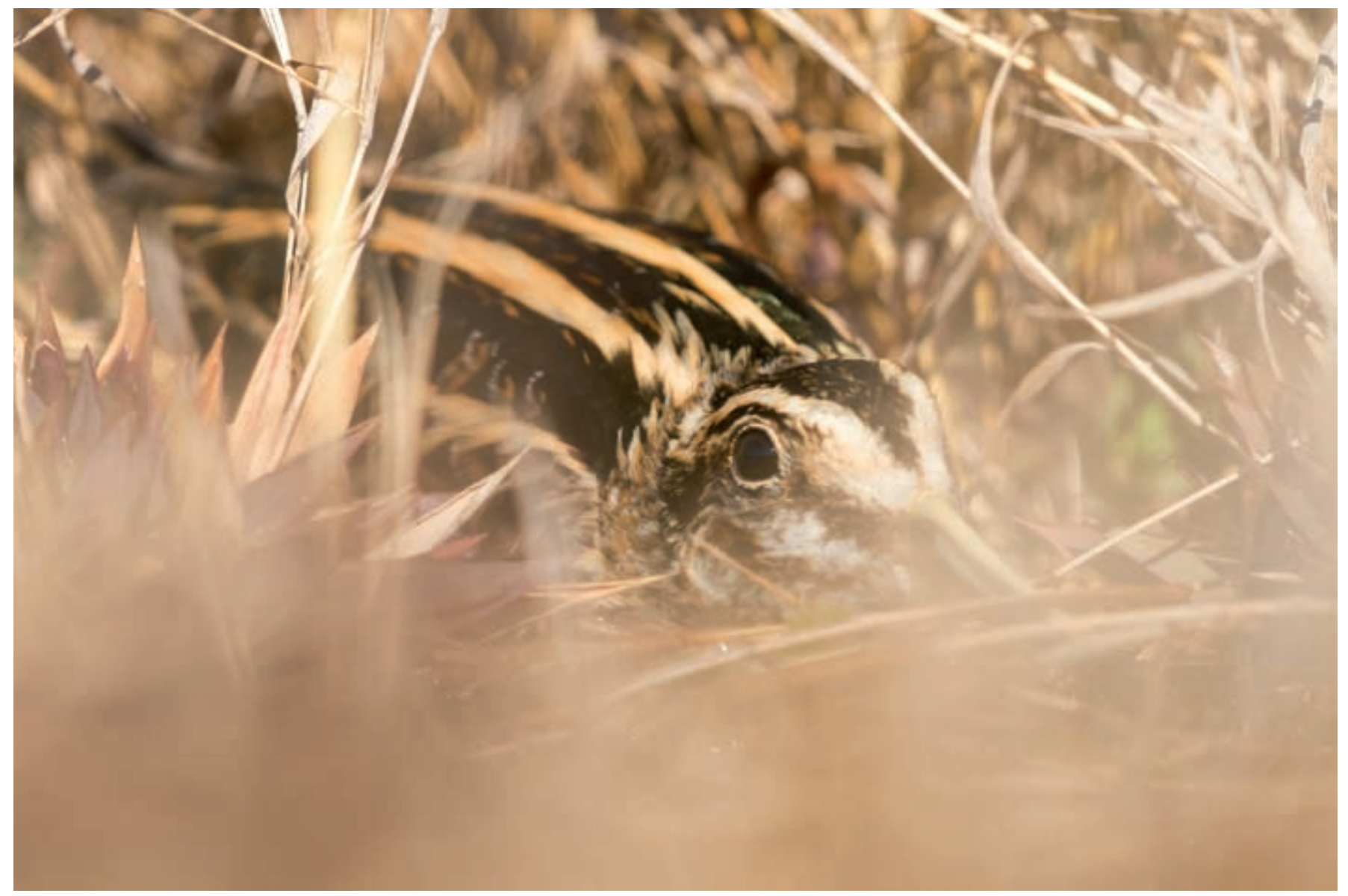

Fig. 4 - Defence behaviour of a Jack Snipe at its diurnal roost, in the the "Baraggia di Candelo Natural Reserve". / Comportamento difensivo di un Frullino al posatoio diurno, nella "Riserva Naturale della Baraggia di Candelo". (Photo by / Foto di Andrea Battisti). 


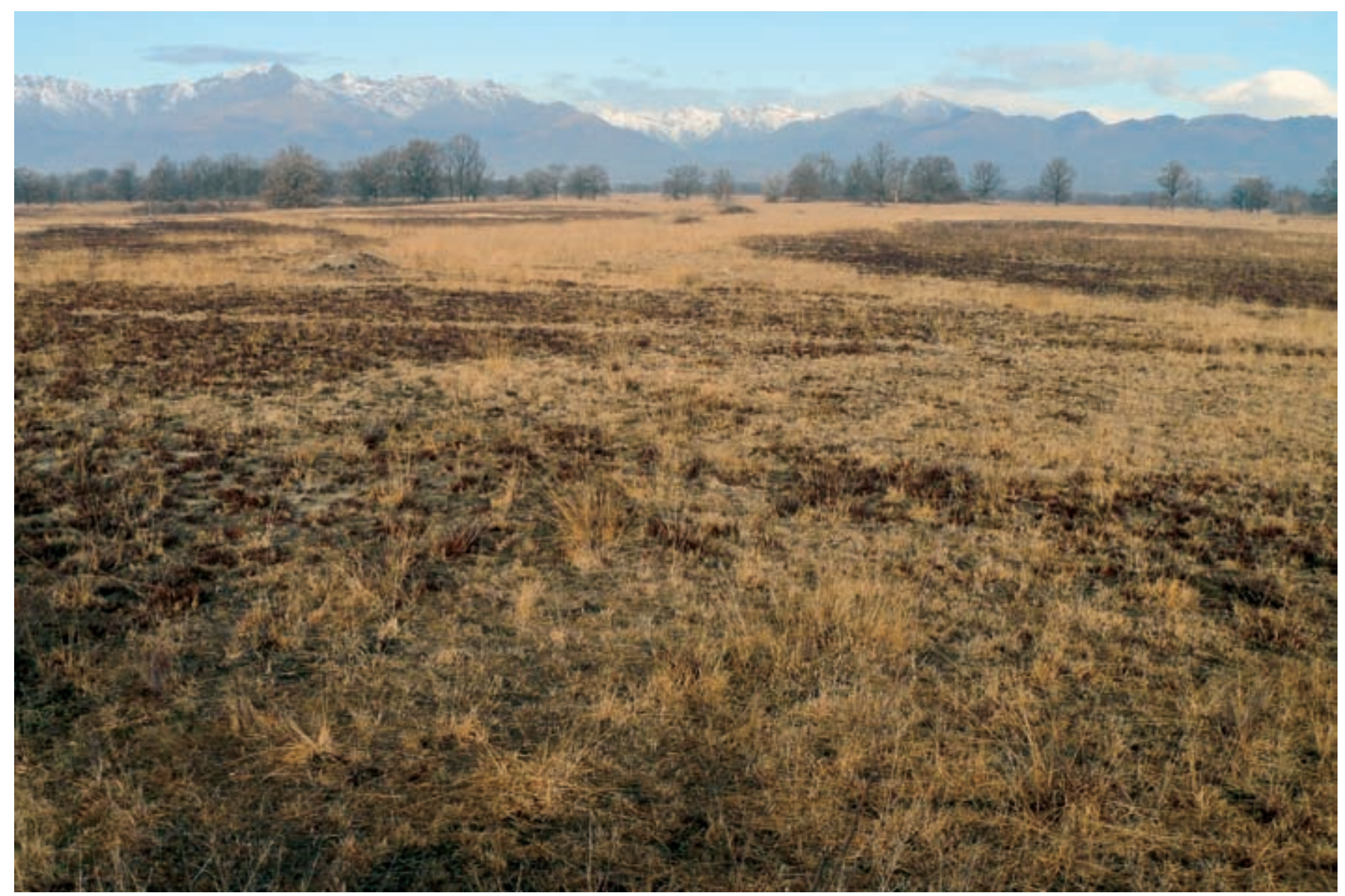

Fig. 5 - The Jack Snipe wintering area in the "Baraggia di Candelo Natural Reserve". / Panorama dell'area di svernamento del Frullino nella "Riserva Naturale della Baraggia di Candelo". (Photo by / Foto di Andrea Battisti).

duals observed in the southern part of the BCNR in the year 2004, with 19 individuals observed together on $11^{\text {th }}$ November (Bordignon, 2004). Jack Snipe seem to visit the BCNR each "cold season", year after year, in the same small areas. We do not know if the birds observed are the same ones each season, but they seem to show site fidelity. The hypothesis of high site fidelity in Jack Snipe is also often reported in the literature (Andrew, 1994; Olivier, 2007), but it has never been tested successfully because of the low number of marked animals.

\section{Acknowledgements}

The authors are very grateful to Giuseppe Bogliani and Giacomo Assandri, who provided helpful comments on the previous version of the article, and to Martin Davies, who provided useful tips and who revised the English. We also thank all the people who at least once took part in a sweep-walk (alphabetical order): Giacomo Assandri, Paolo Becciu, Radames Bionda, Giuseppe Bogliani, Lucio Bordignon, Dario Di Noia, Davide Giuliano, Lorenzo Laddaga, Chiara Lorenzetti, Cristina Novara, Marco Pavia, Irene Pellegrino, Elena Piano, Paolo Ranotto, Paola Rovellini, Marco Saggioro, Massimiliano Tarello and Nestor Vinals. The authors also thanks Gianni Innocenti and Marco Saggioro, two employees who work in the managing of the BCNR, for their interest and passion on this theme. Field work has been possible thanks to the Italian Army and its authorization to access the military area.

\section{REFERENCES}

AERC TAC, 2003 - AERC TAC's Taxonomic Recommendations. $<$ http://www.aerc.eu/DOCS/AERCTAC.pdf $>$

Andrew D. G., 1994 - Site fidelity of Jack Snipe on migration? Scottish Birds, 17: 163.

Arpa Piemonte, 2010 - <http://rsaonline.arpa.piemonte.it/meteocli ma50/pdf/considerazioni_conclusive.pd $>$

Baghino L., Borgo E., Bottero M., Galli L. \& Valfiorito R., 2012 Check-list degli uccelli di Liguria. Rivista Italiana di Ornitologia, Milano, 81 (1):15-42.

Battisti A. \& Bordignon L., 2014 - L'Avifauna del S.I.C. "Baraggia di Candelo IT1130003". Rivista Piemontese di Storia Naturale, 35: 285-301.

Barron D. G., Brawn J. D., Butler L. K., Romero L. M. \& Weatherhead P. J., 2012 - Effects of military activity on breeding birds. The Journal of Wildlife Management, 76 (5): 911-918. <DOI: 10.1002/ jwmg.355>

Beck N. \& Olivier G.-N., 1998 - Régime alimentaire de la bécessine soured (Lymnocryptes minimus) en hivernage dans le nord de la France. Gibier Faune sauvage, Game Wildlife, 15: 259-267.

BirdLife International, 2004 - Birds in Europe: population estimates, trends and conservation status. BirdLife International Conservation, Cambridge, U.K., Series No. 12. 
Brichetti P. \& Fracasso G., 2004 - Ornitologia Italiana. Vol. 2 Tetraonidae Scolopacidae. Alberto Perdisa Editore.

Bocca M. \& Maffei G., 2010 - Check-list degli uccelli della Valle d'Aosta aggiornata al dicembre 2009. Rev. Valdôtain Hist. Nat., 64: 61-74.

Bordignon L., 2004 - L'avifauna delle Baragge. Rapporto di lavoro. Ente di gestione delle "Riserve Pedemontane e delle Terre d'Acqua”, Parco Lame del Sesia.

Coesfeld M. O., 2009 - Die vögel (Vertebrata, Aves) des Truppenübungsplatez Haltern-Borkenberge (Kreise Coesfeld und Recklinghausen). Abhandlungen. Westfälieschen Museum für Naturkunde, 71 (3): 149-170.

Géroudet P., 1983 - Limicoles, gangas et pigeons d'Europe. Vol. 2. Delachaux \& Niestlé, Neuchâtel.

Glutz von Blotzheim U. N., Bauer K. M. \& Bezzel E., 1977 - Handbuck der Vögel Mitteleuropas. Vol. 7. Charadriiformes ( $2^{\text {nd }}$ part $)$. Akademische Varlagsgesellschaft, Wiesbaden.

GPSO (red. Mingozzi T.), 1986 - Resoconto ornitologico per la Regione Piemonte - Valle d'Aosta dal settembre 1984 al dicembre 1985. Rivista Piemontese di Storia Naturale, 7: 181-196.

GPSO (red. Della Toffola M., Maffei G.), 1990 - Resoconto ornitologico per la Regione Piemonte - Valle d'Aosta. Anni 1988 e 1989. Rivista Piemontese di Storia Naturale, 11: 215-237.

GPSO (red. Della Toffola M., Maffei G.), 1991 - Resoconto ornitologico per la Regione Piemonte - Valle d'Aosta. Anno 1990. Rivista Piemontese di Storia Naturale, 12: 145-161.

GPSO (red. Maffei G., Della Toffola M.), 1992 - Resoconto ornitologico per la Regione Piemonte - Valle d'Aosta. Anno 1991. Rivista Piemontese di Storia Naturale, 13: 103-122.

GPSO (red. Maffei G., Della Toffola M.), 1993 - Resoconto ornitologico per la Regione Piemonte - Valle d'Aosta. Anno 1992. Rivista Piemontese di Storia Naturale, 14: 259-279.

GPSO (red. Alessandria G., Della Toffola M., Pulcher C.), 1994 - Resoconto ornitologico per la Regione Piemonte - Valle d'Aosta. Anno 1993. Rivista Piemontese di Storia Naturale, 15: 197-217.

GPSO (red. Alessandria G., Della Toffola M., Pulcher C.), 1996 - Resoconto ornitologico per la Regione Piemonte - Valle d'Aosta. Anni 1994-1995. Rivista Piemontese di Storia Naturale, 17: 205-246.

GPSO (red. Alessandria G., Della Toffola M., Pulcher C.), 1997 - Resoconto ornitologico per la Regione Piemonte - Valle d'Aosta. Anno 1996. Rivista Piemontese di Storia Naturale, 18: 337-374.

GPSO (red. Alessandria G., Della Toffola M., Pulcher C.), 1999 - Resoconto ornitologico per la Regione Piemonte - Valle d'Aosta. Anno 1997. Rivista Piemontese di Storia Naturale, 20: 299-332.

GPSO (red. Alessandria G., Della Toffola M., Pulcher C.), 2000 - Resoconto ornitologico per la Regione Piemonte - Valle d'Aosta. Anno 1998. Rivista Piemontese di Storia Naturale, 21: 337-374.

GPSO (red. Alessandria G., Boano G ., Fasano S., Della Toffola M., Pulcher C., Toffoli R.), 2002 - Resoconto ornitologico per la Regione Piemonte - Valle d'Aosta. Anno 1999. Rivista Piemontese di Storia Naturale, 23: 297-338.

GPSO (red. Alessandria G., Boano G ., Fasano S., Della Toffola M., Pulcher C., Toffoli R.), 2003 - Resoconto ornitologico per la Regione Piemonte - Valle d'Aosta. Anni 2000-2001. Rivista Piemontese di Storia Naturale, 24: 357-408.

GPSO (red. Alessandria G., Boano G ., Fasano S., Della Toffola M., Pulcher C., Toffoli R.), 2004 - Resoconto ornitologico per la Regione Piemonte - Valle d'Aosta. Anno 2002. Rivista Piemontese di Storia Naturale, 25: 391-430.

GPSO (red. Alessandria G., Fasano S., Della Toffola M., Boano G., Pulcher C.), 2005 - Resoconto ornitologico per la Regione Piemonte - Valle d'Aosta. Anno 2003. Rivista Piemontese di Storia Naturale, 26: 321-360.

GPSO (red. Alessandria G., Della Toffola M., Fasano S., Boano G., Pulcher C.), 2006 - Resoconto ornitologico per la Regione Piemonte - Valle d'Aosta. Anno 2004. Rivista Piemontese di Storia Naturale, 27: 349-392.

GPSO (red. Alessandria G., Della Toffola M., Fasano S.), 2007 - Resoconto ornitologico per la Regione Piemonte - Valle d'Aosta. Anno 2005. Rivista Piemontese di Storia Naturale, 28: 383-426.

GPSO (red. Alessandria G., Della Toffola M., Fasano S.), 2008 - Resoconto ornitologico per la Regione Piemonte - Valle d'Aosta. Anno
2006. Rivista Piemontese di Storia Naturale, 29: 355-398.

GPSO (red. Alessandria G., Della Toffola M., Fasano S.), 2009 - Resoconto ornitologico per la Regione Piemonte - Valle d'Aosta. Anni 2007-2008. Rivista Piemontese di Storia Naturale, 30: 225-288.

GPSO (red. Alessandria G., Della Toffola M., Fasano S.), 2010 - Resoconto ornitologico per la Regione Piemonte - Valle d'Aosta. Anno 2009. Rivista Piemontese di Storia Naturale, 31: 279-329.

GPSO (red. Alessandria G., Della Toffola M., Fasano S.), 2011 - Resoconto ornitologico per la Regione Piemonte - Valle d'Aosta. Anno 2010. Rivista Piemontese di Storia Naturale, 32: 297-351.

GPSO (red. Alessandria G., Caprio E., Della Toffola M., Fasano S., Pavia M.), 2012 - Resoconto ornitologico per la Regione Piemonte - Valle d'Aosta. Anno 2011. Rivista Piemontese di Storia Naturale, 33: 337-395.

GPSO (red. Alessandria G., Assandri G., Caprio E., Fasano S., Pavia M.), 2013 - Resoconto ornitologico per la Regione Piemonte - Valle d'Aosta. Anno 2012. Rivista Piemontese di Storia Naturale, 34: 307-366.

Haeberli W. \& Beniston M., 1998 - Climate Change and its Impacts on Glaciers and Permafrost in the Alps. Ambio, 27 (4): 258 - 265.

Jacobson A. R., Provenzale A., Von Hardenberg A., Bassano B. \& Festa-Bianchet M., $2004-$ Climate forcing and density dependance in a mountain ungulate population. Ecology, 85: 1598-1610.

Kalchreuter H., 2003 - On the population status of the Jack Snipe (Lymnocryptes minimus). Game \& Wildlife science, 20 (3):175-193.

Kershner E. L. \& Bollinger E. K., 1996 - Reproductive Success of Grassland Birds at East-central Illinois Airports. The American Midland Naturalist, 136 (2): 358-366. <DOI: 10.2307/2426740>

Olivier G.-N., 2007 - The Jack Snipe Lymnocryptes minimus. Ed. OM$P O / C I C B$, Paris.

Pavia M. \& Boano G., 2009 - Check-list degli Uccelli del Piemonte e della Valle d'Aosta aggiornata al dicembre 2008. Rivista Italiana di Ornitologia, Milano, 79 (1): 23-47.

Scarton, F., Baldin, M. \& Valle. R., 2012 - A new Mediterranean breeding site for the Eurasian Curlew, in Italy. British Birds, 154 (105): 154-159.

Sindaco R., Mondino G. P., Selvaggi A., Ebone A. \& Della Beffa G., 2003 - Guida al riconoscimento di Ambienti e Specie della Direttiva Habitat in Piemonte. Regione Piemonte.

Sindaco R., Savoldelli P. \& Selvaggi A., 2009 - La Rete Natura 2000 in Piemonte. I Siti di Importanza Comunitaria. Regione Piemonte.

Tramontana D., 2014 - Analisi della fenologia migratoria, dei carnieri e delle preferenze ambientali di Beccaccino (Gallinago gallinago) e Frullino (Lymnocriptes minimus) in Italia. Tesi di laurea magistrale in Scienze zootecniche e tecnologie animali. Università degli Studi di Firenze.

Vickery P. D., Hunter M. L. \& Melvin S. M., 1994 - Effects of Habitat Area on the Distribution of Grassland Birds in Maine. Conservation Biology, 8 (4):1087-1097.

Woinarski J. C. Z. \& Ash A. J., 2002 - Responses of vertebrates to pastoralism, military land use and landscape position in an Australian tropical savanna. Austral Ecology, 27 (3): 311-323. 